\title{
Transmission of Monetary Policy through Credit Interest Rates in Turkey: A Microeconomic Perspective
}

\author{
Ilyas Siklar \\ FEAS, Department of Economics, Anadolu University, Eskisehir, Turkey \\ E-mail: isiklar@anadolu.edu.tr
}

Received: November 26, 2021 Accepted: December 21, 2021 Published: December 23, 2021

doi:10.5296/ber.v11i4.19257ＵRL: https://doi.org/10.5296/ber.v11i4.19257

\begin{abstract}
This study aims to examine the monetary policy transmission through the credit channel from a microeconomic perspective by using the fixed effect dynamic panel model. It is estimated to what extent policy interest rate changes are transferred to the short-term interest rate depending on the type of loan. Results confirm that there is a high degree of inertia in both the commercial and consumer loan interest rates. In terms of the transmission of monetary policy, changes in policy interest rates are transferred to commercial loan interest rates by $11 \%$ and consumer loan interest rates by $15 \%$ in the short term. These values reveal that policy interest rate changes are gradually transmitted to market interest rates. Variables representing bank size, leverage, and market power in terms of distinctive characteristics have a limited impact on both commercial and consumer loan interest rates in the analyzing period. However, the market share of a bank has a significant impact on both commercial and consumer loan rates.
\end{abstract}

Keywords: Transmission of monetary policy, Credit channel, Bank-specific characteristics, Dynamic panel

\section{Introduction}

Monetary policy has an important role in softening the business cycle fluctuations in an economy. This is evidenced by the fact that many central banks around the world have agreed to maintain price stability or keep the growth in economic activity around the potential rate as their goal. A central bank has multiple instruments that affect a targeted macroeconomic aggregate through different transmission channels. Among these instruments, interest rate changes come to the fore. Recently, the most important ones among the mentioned transmission channels can be listed as (i) interest rate, (ii) inflation expectations and central bank credibility, (iii) financial asset prices, and (iv) exchange rate channels (Endut et. al., 2018). 


\section{Macrothink}

Business and Economic Research

ISSN 2162-4860

2021, Vol. 11, No. 4

The credit channel, which is known as the effect of policy interest rate changes on loan interest rates and thus loan demand, is the main transmission channel for Turkey. This is because during the review period, the rate of economic growth in Turkey is largely determined by domestic demand (see Figure 1), and domestic demand can be accelerated or limited by changing the cost of borrowing.

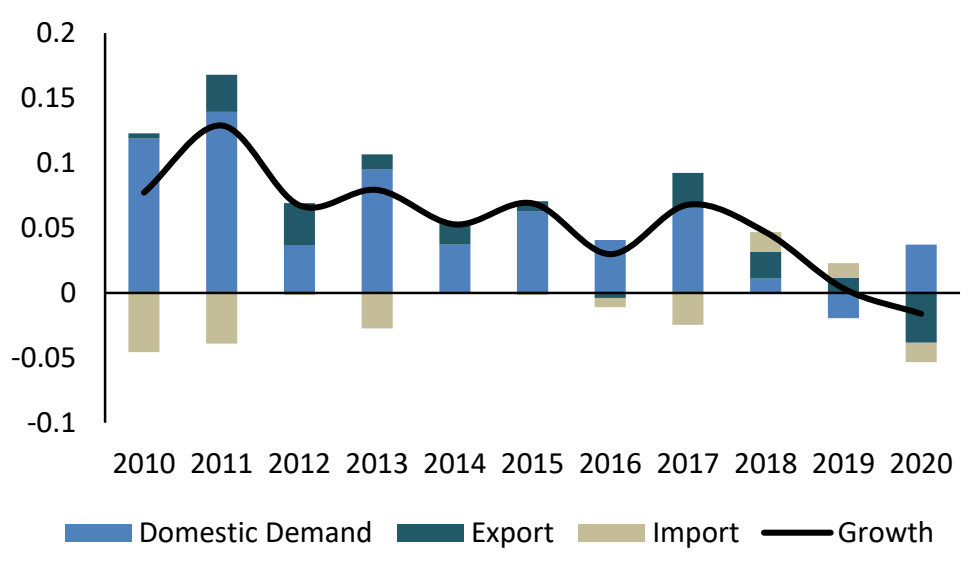

Figure 1. Relative Contributions to Economic Growth

Source: TURKSTAT

In countries where capital markets are still developing, the importance of the credit channel is increasing as companies finance their investments through loans rather than issuing bonds (Byrne \& Kelly, 2019). In this context, although Turkey has recently exhibited a significant acceleration in financial development, the ratio of loans to GDP is still around 69\% (see Figure 2). This rate is one of the lowest among the countries in the same development category as Turkey during the review period.

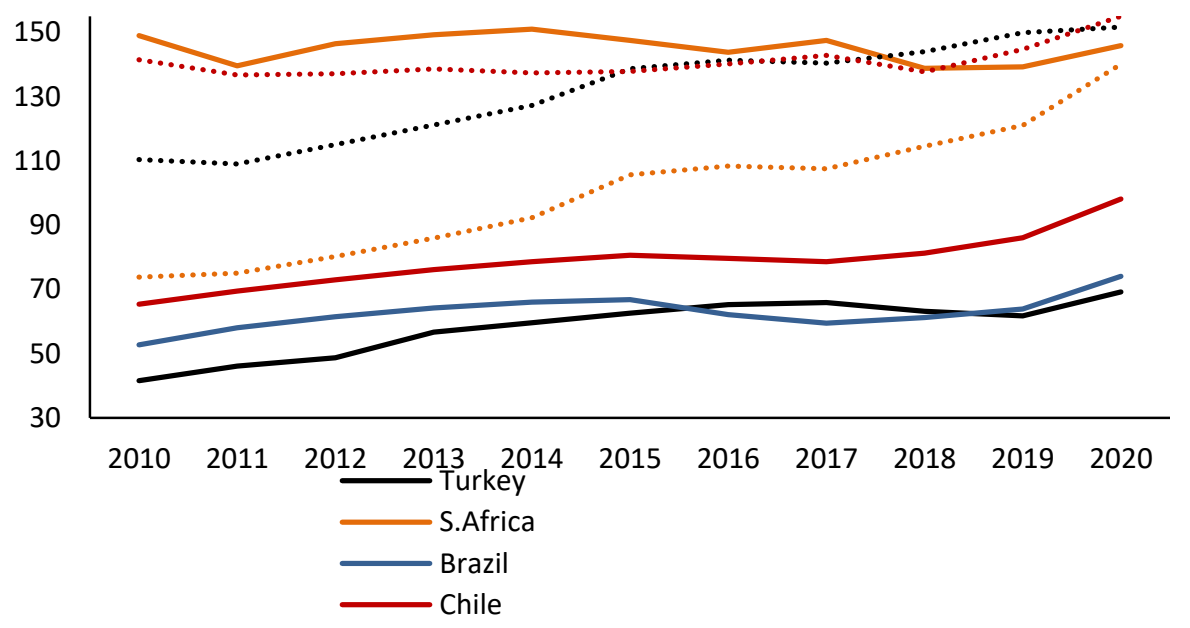

Figure 2. Credit/GDP Ratio in Various Countries and Country Groups

Source: World Development Indicators, 2021 


\section{I Macrothink}

Due to the importance briefly summarized above, it is essential to analyze the transmission of monetary policy through the credit channel. Figures 3 and 4 show the course of average, maximum, and minimum real interest rates for commercial loans and consumer loans together with the real policy interest rate during the review period $(2010-2020)$. This study aims to consider the relationship between interest rates summarized in graphs from a microeconomic perspective and to use bank-based data to determine the effect of monetary policy interest rate changes on short-term interest rates. In addition, bank-specific features (size, market power, leverage level, profitability, and loan portfolio quality) are included in the model as factors that explain interest rate differences among banks and strengthen or weaken the transmission of monetary policy to market interest rates.

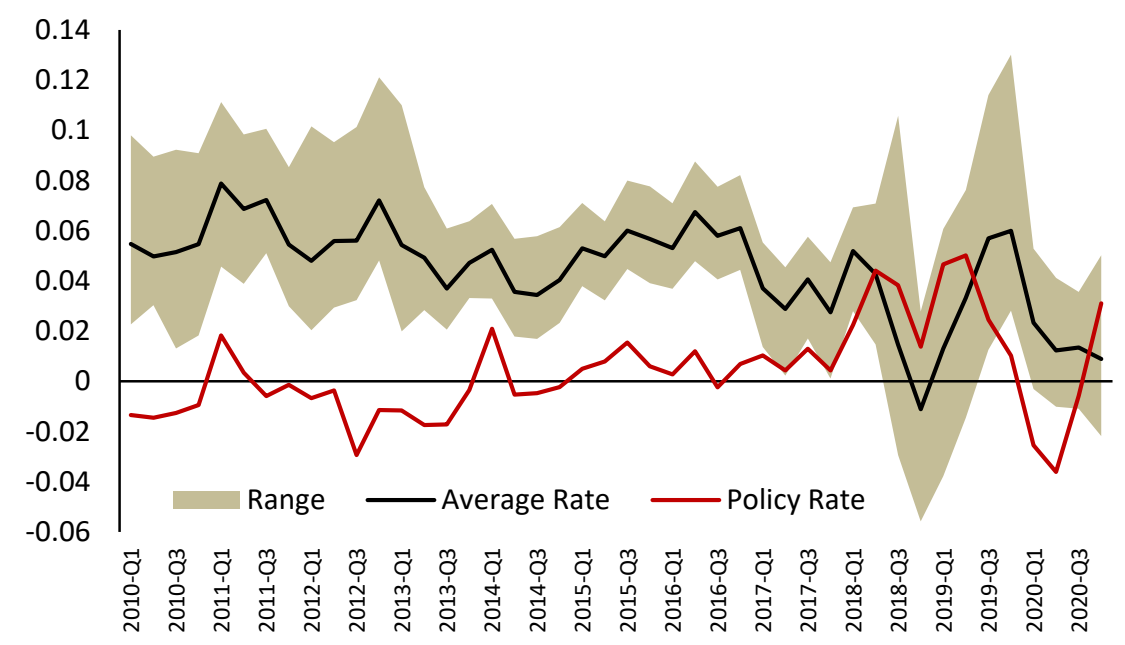

Figure 3. Commercial Loan Real Interest Rate and Monetary Policy Real Interest Rate Source: The Banks Association of Turkey

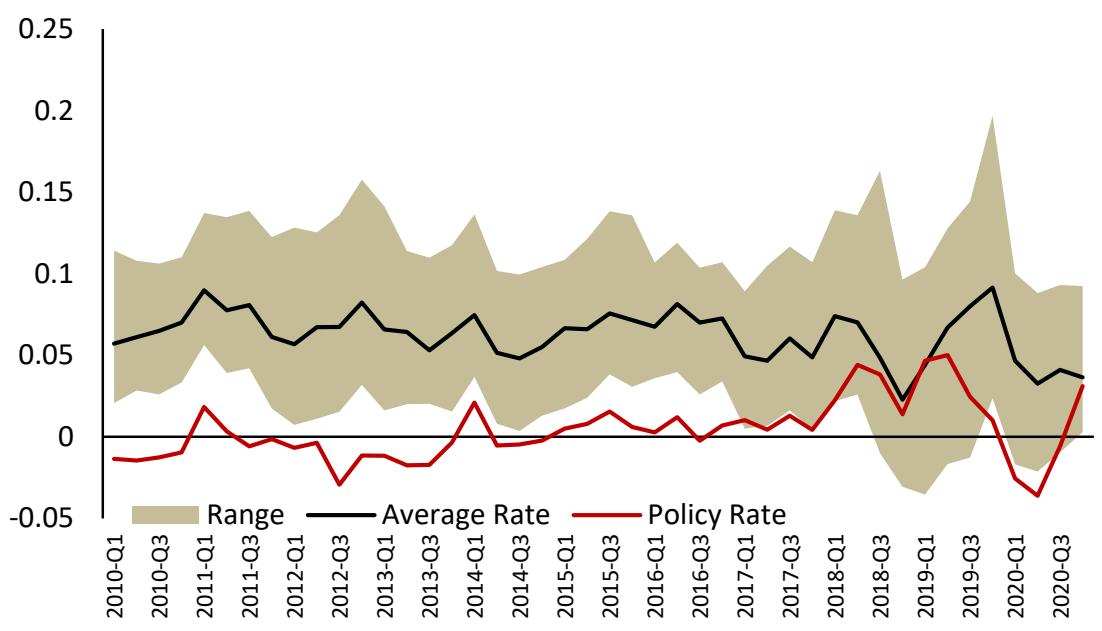

Figure 4. Consumer Loan Real Interest Rate and Monetary Policy Real Interest Rate Source: The Banks Association of Turkey 
Considering that the previous studies on Turkey mostly examined the credit channel in macroeconomic level, this study differs from the others with the micro-econometric methods to be applied. On the other hand, a small number of previous studies on a microeconomic basis consider the credit volume as a whole. Considering that consumer and commercial loans reflect the behavior of households and the business world, respectively, it can be stated that the integrated perspective is incomplete. The risk and maturity of the loans and the characteristics of the borrower have an impact on these behaviors. This study will allow determining the effect of the behavior of the mentioned economic units by considering commercial loans and consumer loans separately.

The importance of adequate transmission of policy rate changes is undisputed since this transmission increases the control power of the monetary authority over aggregate demand and therefore prices. Considering that the loan demand will respond to interest rate changes in the longer term, it is a correct approach to treat the short term while analyzing the transmission of the policy rate to loan interest rates. Therefore, in the event of a demand shock in economic activities, the power of the monetary authority to change the real sector borrowing cost as quickly as possible becomes important. Although the long-term effect is greater, it occurs as a result of gradual changes that are of greater importance in the short term.

Regarding these issues, the model to be applied should be a dynamic panel in which the lagged dependent variable is among the explanatory variables to determine the effect of the policy interest rate change on the loan interest rate of each financial institution. In addition, fixed effects should be included in the model to see the effect of observable and unobservable features of financial institutions on loan interest rates. Finally, the statistical method used in the estimation phase is the generalized least squares. This method allows to correct the heteroscedasticity and simultaneous correlation of errors among the cross-sections in the panel. Considering the existence of common features of banks and the existence of externalities that the behavior of one of them will create on the others, this approach will contribute to the robustness of the model.

The structure of the study is as follows: After this introduction, which forms the first part, the second part deals with the literature review, in which the variables that allow explaining the behavior of the loan interest rate are determined. The third section discusses the estimation process and describes in detail (i) the preferred statistical method and (ii) the data used. While the fourth section summarizes the results disaggregated by loan type, the fifth section includes key conclusions and policy recommendations.

\section{Recent Empirical Literature}

Monetary transmission is a subject that has been studied extensively throughout history. Since it is important for monetary authorities to control aggregate demand in countries that implement inflation targeting regimes, the credit channel is of particular importance in these countries. In general terms, the approach used to determine the effect of changes in monetary policy interest rate on other variables is the macroeconomic perspective by nature. However, some researchers appeal to the problem from a micro-econometric perspective using dynamic 
panels. In this approach, in addition to the policy interest rate and bank-specific characteristics, the lagged dependent variable is also included among the explanatory variables. The use of the series at their levels after the presence of the unit root is rejected is a distinguishing factor for many studies. The literature will greatly assist in the selection of variables (such as leverage, market power, asset size) that explain differences in banks' response to policy interest rate changes.

According to Bernanke \& Gertler (1995), De Fiore \& Tristani (2013), and Byrne \& Kelly (2019), one of the channels that monetary policy affects the economy works through the funding cost of credit institutions. The cost of funds incurred by credit institutions affects the interest rate of the loans to be given by these institutions, thus supporting or limiting the total demand. Gambacorta \& Shin (2018) states that for a number of international banks in developed economies, the level of leverage has a significant impact on the transfer of support provided by the central bank. A one-percentage-point decrease in the ratio of assets to equities creates a 4 percentage-point decrease in the financing costs of financial institutions. As it means that policy rate changes are reflected to loan interest rates to a greater extent, this situation ensures that the transfer of the monetary policy to the real sector accelerates. Gregor \& Melecky (2018) find that leverage is the main variable that explains the loan interest rate changes of banks in the Czech Republic and the interest rate differences between financial institutions, and they identify a lower transmission in commercial loans. Holton \& Rodriguez (2018) concludes that high leverage in the Eurozone slows the transmission to large-scale business-related loans.

Another variable that is generally included in the analysis in the former studies is the market power and its negative effect on the transmission of the policy rate to the loan rate. Liu et.al. (2018) in China, Van Leuvensteijn et.al. (2013) in the Eurozone, Karagiannis et.al. (2014) in BRIC countries, Altinoz \& Ozdemir (2012) in emerging markets (it is stated that competition plays a larger role), Fuertes et.al. (2010) in the UK and Khan \& Khan (2010) in Pakistan prove the validity of this situation. The last two studies mentioned above determine that the difference between banks' commercial loan interest rates is positively related to market power. In the case of England, it is determined that the market power creates an asymmetric effect depending on the direction of the change in the policy rate. The variable in question can be measured with different indicators. Among these, the Lerner Index (as the representative of price-setting power) and the market share (representing the share of each institution in total loans) are the most used ones.

Another bank-specific characteristic that affects the transmission of monetary policy is the size of assets. Holton \& Rodriguez (2018) generally determine this result in small-scale loans (especially for consumer loans), while Byrne \& Kelly (2019) determine the same in European countries.

The variable that is most intensively addressed in terms of the characteristics of banks is the quality of the loan portfolio or the relationship between non-performing loans and total loans. Basically, poor portfolio quality means higher financing costs, which in turn causes rigidities in the loan rate (especially in the case of policy rate reductions). The negative impact of the 
problems encountered in the repayment of loans is revealed in Holton \& Rodrigues (2018)'s study on the Euro Zone. On the other hand, in this study, it is determined that the transmission in commercial loans is higher than consumer loans. Byrne \& Kelly (2019) find that the deterioration in the quality of the loan portfolio explains the differences in the degree of transmission in European countries after the financial crisis, and if defaulting ratio reaches $17 \%$, it completely inhibits monetary policy transmission.

Finally, Cruz-Garcia et al. get. (2019) confirms that the decrease in the policy rate reduces the intermediation margin in the long run. This is a feature set by some organizations such as the IMF since the decrease in the cost of indebtedness in the short run is in favor of financial institutions and increases the intermediation margin. However, if loan interest rates accompany this decrease, the intermediation margin may decrease. Aydemir \& Ovenc (2016) find that this effect is stronger in emerging markets.

According to the studies mentioned above, other factors affecting the volatility in interest rates include the level of capitalization (Stanislawska, 2015), level of liquidity, independence from central bank funding (measured by the share of deposits in liabilities). On the other hand, country risk and other macroeconomic variables gain importance in comparisons between countries.

In Turkey-related studies, since transmission of monetary policy is generally investigated with the macroeconomic perspective, they use time series techniques and are based on the supply of loans rather than the credit interest rates. Therefore, studies in which transmission mechanism operates through interest rates considering the type of credit and bank-specific characteristics are limited. For instance, by using bank-level data to determine the relationship between short-term interest rates (interbank rate and the Central Bank average funding rate instead of policy rate) and bank rates (including the deposit rates), Binici, Kara \& Ozlu (2019) conclude that the interbank rates are the main drivers of loan rates in the Turkish banking system. Therefore, their results imply that banks are more concerned with the Central Bank's actions rather than the level of or change in the policy rate. However, most of the bank-specific characteristics they use (assets size, deposits/assets ratio, non-performing loans ratio, capital ratio) do not have a statistically meaningful effect on commercial, consumer and deposit rates in the system.

Sengonul \& Thorbecke (2005) investigates the relationship between contractionary monetary policy and loan supply by using Kashyap \& Stein (2000) methodology. Findings prove the negative effect of tight monetary policy on the supply of loans depending on the scale of banks included in their samples. Although they have used a non-linear time series model (TVAR), Catik \& Karacuka (2012) conclude that the impact of monetary variables on the credit volume of the banking system In Turkey is limited. Aydın \& Igan (2012), on the other hand, analyze the bank-level data for the 2002 - 2008 period to estimate the effects of monetary and fiscal policies on the credit growth rate in Turkey. Instead of policy interest rate, they use annual inflation rate, discount rate, and interbank money market lending rate as the indicators of monetary policy stance and reach the conclusion that the stance of monetary policy forces banks to change the maturity of loans. They do not refer to the effect of 
bank-specific characteristics on the aggregated credit volume or its average interest rate. Recently, Sahin (2019), using dynamic panel estimation techniques, tests whether monetary policy indicators had an impact on loan supply. By using sectoral data, she concludes that the credit channel is especially important for small and medium-sized enterprises. Turguttopbas (2019) aims to analyze the impact of monetary policy on lending rates with the data constructed at the bank level. She concludes that a change in the policy rate of the Central Bank affects credit interest rates in three months through deposit rates. However, the panel data analyzing side of the study focuses on the ratio of credits to total assets rather than the lending rates.

As can be seen, while most of the studies specific to Turkey focus on the loan volume, they do not distinguish between loan types and do not include bank-specific characteristics in the analysis.

\section{Estimation}

\subsection{Methodology}

In this study, a panel with fixed effects is estimated for each type of loan (consumer and commercial loans) as it is suitable to consider the different observable and unobservable characteristics of each bank. The estimation method chosen is the generalized least squares method. This method allows correcting (i) the heteroscedasticity resulting from the behavior of each unit and (ii) the simultaneous correlation of the cross-sectional error terms in the panel. These two aspects are the result of the units in the panel having common features and the behavior of one unit creating an externality for the others. On the other hand, these features are quite common in panels with a limited number of units because this specification increases the probability that the behavior of one unit will affect the behavior of others. For this reason, the simultaneous conditional correlation of errors among different financial institutions is handled as follows to prevent bias in estimations:

$$
\left.\begin{array}{c}
E\left(\varepsilon_{i t} \varepsilon_{j t} \mid x_{t}^{*}\right)=\sigma_{i j} \\
E\left(\varepsilon_{i s} \varepsilon_{j t} \mid x_{t}^{*}\right)=0
\end{array}\right\} \text { for all } \mathrm{i}, \mathrm{j}, \mathrm{t}, \text { and } \mathrm{s}(\text { as long as } \mathrm{s} \neq \mathrm{t})
$$

It should be mentioned that simultaneous covariances do not change with time, so the matrix of variances and covariances is structured as follows:

$$
\begin{gathered}
E\left(\varepsilon_{t} \varepsilon_{t}^{\prime} \mid x_{t}^{*}\right)=\Omega_{N} \\
\Omega_{N}=\left[\begin{array}{ccc}
\sigma_{11} & \cdots & \sigma_{1 N} \\
\vdots & \ddots & \vdots \\
\sigma_{N 1} & \cdots & \sigma_{N N}
\end{array}\right]
\end{gathered}
$$

Since the parameters and variance-covariance will be estimated in two stages in the estimation process, the robustness of the model increases in case of problems arising from the heteroscedasticity and autocorrelation in error terms. This is possible thanks to the sample size (long panel). 


\section{Macrothink}

The equations to be estimated for each panel, one for the commercial loan interest rate and the other for the consumer loan interest rate, are as follows:

$$
\begin{aligned}
\operatorname{rcom}_{i, t}=\theta_{i} & +\sum_{l=2}^{n} \alpha_{j} \operatorname{rcom}_{i, t-l}+\sum_{k=1, j=0}^{n}\left(\beta_{j}+\eta_{k} Z_{i, t-k}\right) \operatorname{rpol}_{t-j}-\gamma_{i} \operatorname{rcom}_{i, t-1} \\
& +\sum_{j=1}^{n} \mu_{j} Z_{i, t-j}+\varepsilon_{i, t} \\
\operatorname{rcon}_{i, t}=\theta_{i}+ & \sum_{l=2}^{n} \alpha_{j} \operatorname{rcon}_{i, t-l}+\sum_{k=1, j=0}^{n}\left(\beta_{j}+\eta_{k} Z_{i, t-k}\right) \operatorname{rpol}_{t-j}-\gamma_{i} \operatorname{rcon}_{i, t-1} \\
& +\sum_{j=1}^{n} \mu_{j} Z_{i, t-j}+\varepsilon_{i, t}
\end{aligned}
$$

In this equation, rcom and rcon represent the commercial loan and consumer loan weighted real interest rate, respectively, while rpol is the central bank real policy rate. The presence of the lagged dependent variable among the explanatory variables makes the model dynamic. This is the method used in all of the studies discussed in the previous section. This eliminates the Nickell bias that can occur when working with a long panel [few units (18) and many periods (44)]. The constant terms $\left(\theta_{i}\right)$ in the equations measure the effect of unobservable heterogeneity among banks. The direct effect of policy interest rate on commercial and consumer loan interest rates is measured with the parameter $\beta_{j}$. The sum of the $\beta_{j}$ parameters, as a result of including the policy interest rate in the model with multiple lags $(j>1)$, expresses the effect of monetary policy on loan interest rates in the short run. The model also includes the lagged $Z_{i, t-k}$ vector expressing bank-specific characteristics. Thus, it becomes possible to determine the effect of bank-specific characteristics (such as a deterioration in the quality of the loan portfolio, a change in the leverage level) on loan interest rates employing the $\mu_{j}$ parameter. On the other hand, by multiplying the policy interest rate with $Z_{i}$, the relationship between the bank characteristics and the policy interest rate can be determined by the parameter $\eta_{k}$.

\subsection{Data}

In the previously mentioned literature, variables related to the individual characteristics of banks are also used in this study. It is possible to list these variables and their definitions as follows:

(i) Lerner Index $\left(L I_{i, t}\right)$ : Using the average weighted deposit interest rate $\left(r d e p_{i, t}\right)$ to express marginal cost, this variable which is used as an indicator of market power is calculated for each bank as follows:

$$
L I_{i, t}^{\mathrm{com}}=\frac{\operatorname{rcom}_{i, t}-\operatorname{rdep}_{i, t}}{\operatorname{rdep}_{i, t}}
$$




$$
L I_{i, t}^{c o n}=\frac{\operatorname{rcon}_{i, t}-r d e p_{i, t}}{r d e p_{i, t}}
$$

(ii) Asset Size $\left(A S S E T_{i, t}\right)$ : It is defined as the total assets included in the periodic balance sheet of each bank as an indicator of the size of the bank.

(iii) Leverage $\left(L E V_{i, t}\right)$ : Leverage, which is used as an indicator of the resource structure of the banking system and the risk undertaken, is defined as the ratio of total assets to equity $\left(E Q U I T Y_{i, t}\right)$ :

$$
L E V_{i, t}=\frac{A S S E T_{i, t}}{E Q U I T Y_{i, t}}
$$

(iv) Loan Portfolio Quality $\left(Q_{U A L I T Y}{ }_{i, t}\right)$ : This variable, which is used to evaluate the quality of the loan portfolio, is calculated as the ratio of non-performing loans $\left(N P L_{i, t}\right)$ to total loans (TOTCREDIT $\left.T_{i, t}\right)$ :

$$
Q U A L I T Y_{i, t}=\frac{N P L_{i, t}}{\text { TOTCREDIT }}
$$

(v) Return on Assets Ratio $\left(R O A_{i, t}\right)$ : This variable, which is used as an indicator of the bank's management efficiency and profitability, is calculated as the ratio of net profit $\left(N P R O F_{i, t}\right)$ to total assets:

$$
R O A_{i, t}=\frac{N P R O F_{i, t}}{A S S E T_{i, t}}
$$

(vi) Market Share $\left(M S_{i, t}\right)$ : This variable, which is defined as the share of each bank included in the data set in total commercial loans and total consumer loans, is used as an indicator of the relevant bank's market share:

$$
\begin{aligned}
M S_{i, t}^{C O M} & =\frac{\operatorname{COM}_{i, t}}{\text { Tot.Com.Cr }} \\
M S_{i, t}^{C O N} & =\frac{\operatorname{CON}_{i, t}}{\text { Tot.Con.Cr }}
\end{aligned}
$$

In addition to those described above, dummy variables related to each bank characteristic were created within the framework of the principle of:

\section{Dummy Variable $\begin{cases}1 & \text { if the bank is in the top } 35 \% \\ 0 & \text { otherwise }\end{cases}$}

Dummy variables are included in the model to avoid the endogeneity problem for the variables. Following the literature, each variable is included in the model with two lags, and the variables that are not statistically significant are excluded one by one to reach the final estimate. To estimate a balanced panel, 18 of the 33 commercial banks operating in the Turkish banking system throughout the investigation period $(2010-2020)$ were considered. A database was created by making use of the financial statements and annexes of these 18 
commercial banks published quarterly for the period of 2010 - 2020. By excluding a small bank in the banking system due to its outliers, data from 17 banks will be used in the estimation phase. All the data used in the creation of the relevant variables have been obtained from the financial statements and their annexes published by the Banks Association of Turkey. Monetary policy interest rate and consumer price index data have been retrieved from the Electronic Data Delivery System of the Central Bank of the Republic of Turkey. The list of banks included in the panel is given in the Appendix at the end of the study.

\section{Estimation Results}

\subsection{Preliminary Tests}

Before estimating the relevant models, the stationarity properties of the time series were examined employing unit root tests. It is possible to have an idea about the typical behavior of stationary time series (such as mean-reverting) by graphing them. Figure 5 indicates that the relevant interest rates do not show a clear trend and generally fluctuate around the mean. For this reason, it would be appropriate for unit root tests to include constant terms but not trend parameters.

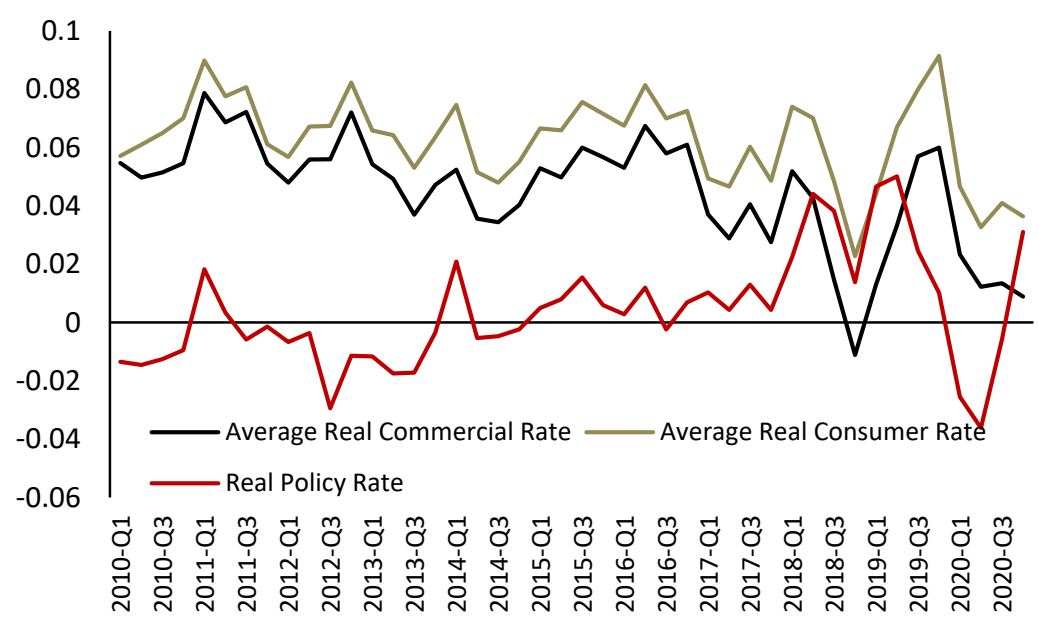

Figure 5. Average Real Interest Rates

Source: Own calculations

Three types of unit root tests were applied to the related time series under the constant term and no-trend configuration. In the first test, the existence of a common unit root among the cross-sections of the panel was tested by the Levin, Lin \& Chu method. The other two tests are the Im, Pesaran \& Shin and ADF panel unit root tests, to test the existence of an individual unit root. All three test results summarized in Table 1 prove that the panel data on commercial and consumer loan real interest rates are stationary at their levels and do not contain unit roots. 
Table 1. Results of Unit Root Tests

\begin{tabular}{|l|l|l|l|l|}
\hline \multirow{2}{*}{ Test } & \multicolumn{3}{|l|}{ RCOM } & \multicolumn{2}{l|}{ RCON } \\
\cline { 2 - 5 } & Test Statistic & Probability & Test Statistic & Probability \\
\hline Levin, Lin \& Chu $\left(\mathrm{t}^{*}\right)^{*}$ & 5.8291 & 0.0000 & 6.6418 & 0.0000 \\
\hline Im, Pesaran \& Shin $(\mathrm{W})^{* *}$ & 4.7582 & 0.0000 & 6.1253 & 0.0000 \\
\hline ADF - Choi (Z) ${ }^{* *}$ & 4.5693 & 0.0000 & 6.1115 & 0.0000 \\
\hline
\end{tabular}

Note: * and ** refer to the tests for common and individual unit root processes, respectively.

\subsection{Determination of Fixed Effects}

The fixed effects specification is appropriate to take into account the unobservable characteristics of the units in the panel. The validity of this specification is checked for both types of loan interest rates using the Redundant Fixed Effects test and the Haussman Fixed Effects vs Random Effects specification test. The test results are summarized in Table 2.

Table 2. Fixed Effects - Random Effects Specification Tests

\begin{tabular}{|l|l|l|l|l|l|l|}
\hline \multirow{2}{*}{ Variable } & \multicolumn{4}{|l|}{ Haussman Test for Specification } & \multicolumn{3}{l|}{ Fixed Effects Redundancy Test } \\
\cline { 2 - 7 } & $\chi^{2}$ Statistic & Degrees of Freedom & Probability & F Statistic & Degrees of Freedom & Probability \\
\hline rcom & 22.8003 & 6 & 0.0009 & 4.4183 & $16 ; 708$ & 0.0000 \\
\hline rcon & 26.4878 & 6 & 0.0000 & 3.2406 & $16 ; 708$ & 0.0000 \\
\hline
\end{tabular}

\subsection{Preliminary Estimation}

To determine the length of lagged dependent variable and the number of lags of the policy interest rate, the basic model is estimated separately for both interest rates. Schwarz criterion is used to choose the optimal lag lengths. The results for this preliminary estimate are summarized in Table 3. According to the table, the lagged dependent variable is included in the model with a one-period lag, while the policy interest rate is included in the model with its current and one-period lagged values. Related diagnostic tests confirm these determinations.

Table 3. Basic Models for Interest Rates

\begin{tabular}{|c|c|c|c|c|c|c|}
\hline \multirow{3}{*}{ Independent Variables } & \multicolumn{6}{|c|}{ Dependent Variable } \\
\hline & \multicolumn{3}{|l|}{ RCOM } & \multicolumn{3}{|l|}{ RCON } \\
\hline & Coefficient & t statistic & Probability & Coefficient & t statistic & Probability \\
\hline Constant & 0.0074 & 4.8735 & 0.0000 & 0.0137 & 7.7057 & 0.0000 \\
\hline$R C O M_{t-1}$ & 0.7968 & 34.759 & 0.0000 & 0.7585 & 32.073 & 0.0000 \\
\hline$R P O L_{t}$ & 0.3563 & 4.8255 & 0.0000 & 0.4898 & 7.2611 & 0.0000 \\
\hline$R P O L_{t-1}$ & -0.2236 & 2.9673 & 0.0031 & -0.3331 & 4.7805 & 0.0000 \\
\hline Adjusted $R^{2}$ & 0.8858 & & & 0.8831 & & \\
\hline Wald $\chi^{2}(3)^{*}$ & 32.184 & & 0.0000 & 47.853 & & 0.0000 \\
\hline Observations & 748 & & & 748 & & \\
\hline Groups & 17 & & & 17 & & \\
\hline
\end{tabular}

$(*)$ number in parenthesis indicates degrees of freedom for $\chi^{2}$ test. 
In the reduced models for both types of interest rates, it is seen that a 100 basis points change in the policy interest rate is reflected in the commercial loan interest rate by approximately 13 basis points and in the consumer loan interest rate by approximately 16 basis points. These transmission values are expected to decrease when bank-specific characteristics are included in the model.

\subsection{Final Estimation Results}

The results of the commercial loan interest rate model and consumer loan interest rate model estimated by including bank-specific variables are given in Table 4. Regarding the consistency of the estimations, the results of the tests for omitted variables and residual cross-section dependency are given in Tables 5 and 6 , respectively.

Table 4. Final Estimation Results

\begin{tabular}{|c|c|c|c|c|c|c|}
\hline \multirow{3}{*}{ Independent Variables } & \multicolumn{6}{|c|}{ Dependent Variable } \\
\hline & \multicolumn{3}{|l|}{ RCOM } & \multicolumn{3}{|l|}{ RCON } \\
\hline & Coefficient & t statistic & Probability & Coefficient & t statistic & Probability \\
\hline Constant & 0.0319 & 5.0571 & 0.0000 & 0.0244 & 3.9044 & 0.0001 \\
\hline rcom $_{t-1}$ & 0.8143 & 31.565 & 0.0000 & - & - & - \\
\hline $\operatorname{rcon}_{t-1}$ & - & - & - & 0.8767 & 44.578 & 0.0000 \\
\hline rpol & 0.4717 & 9.3552 & 0.0000 & 0.6396 & 10.642 & 0.0000 \\
\hline rpol $_{t-1}$ & -0.3601 & 7.1341 & 0.0000 & -0.4870 & 8.7177 & 0.0000 \\
\hline lassets & -0.0017 & 2.5313 & 0.0116 & - & - & - \\
\hline lassets $_{t-1}$ & - & - & - & -0.0022 & 3.2916 & 0.0010 \\
\hline leverage & 0.0003 & 2.1693 & 0.0198 & - & - & - \\
\hline leverage $_{t-1}$ & - & - & - & -0.0008 & 3.0677 & 0.0022 \\
\hline lercom & 0.0001 & 2.0407 & 0.0401 & - & - & - \\
\hline lercon & - & - & - & 0.0001 & 1.6985 & 0.0898 \\
\hline mscom $_{t-1}$ & 0.0228 & 2.0461 & 0.0398 & - & - & - \\
\hline $\operatorname{mscon}_{t-1}$ & - & - & - & 0.0438 & 2.2956 & 0.0220 \\
\hline dasquality & -0.1514 & 2.0638 & 0.0394 & -0.1779 & 2.1976 & 0.0238 \\
\hline dasquality $_{t-1}$ & 0.1952 & 2.2640 & 0.0205 & 0.2098 & 2.5124 & 0.0122 \\
\hline droa $_{t-1}$ & - & - & - & -0.1096 & 1.6588 & 0.0976 \\
\hline Adjusted $R^{2}$ & 0.6308 & - & - & 0.7511 & - & - \\
\hline Wald $\chi^{2}(10)^{*}$ & 75.585 & & 0.0000 & - & - & - \\
\hline Wald $\chi^{2}(11)^{*}$ & - & - & - & 27.480 & - & 0.0000 \\
\hline Observations & 731 & - & - & 731 & - & - \\
\hline Groups & 17 & - & - & 17 & - & - \\
\hline
\end{tabular}

$\left(^{*}\right)$ number in parenthesis indicates degrees of freedom for $\chi^{2}$ test.

According to the estimates, the factors determining the commercial loan interest rate during the analyzing period can be listed as: Policy interest rate (current and lagged), bank size (in logarithms), leverage, market power, market share (lagged), and asset quality (current and lagged). Among the explanatory variables, the high value of the lagged dependent variable indicates the existence of high inertia in commercial loan interest rates. A 100 basis points increase in the borrowing cost observed in the quarter before the current period is seen together with the 81 basis points increase in the $t$ period interest rate. This proves the presence of strong inertia. In terms of monetary policy decisions, the results show the 
existence of limited transmission in Turkey, contrary to the research results mentioned earlier. A 100 basis points increase in the policy rate is reflected in the commercial loan interest rate as approximately 11 basis points in the quarter after the decision. This indicates that there is an average transmission of $10 \%$ throughout the period. Considering that the previously mentioned studies have determined transmission rates between $15 \%$ and $60 \%$, the estimated rate of policy transmission for commercial loans interest rates during the analyzing period in Turkey is pretty low.

The results obtained in terms of bank characteristics can be summarized as follows: Although they are statistically significant, the effect of bank size, leverage, and market power on the commercial loan interest rate is limited. A one-point increase in these variables results in a change of $-0.0017,0.0003$, and 0.0001 points in the commercial loan interest rate, respectively. Although they have a very limited effect, the coefficients have expected signs and are statistically significant. In terms of commercial loan interest rates, variables related to the bank's market share and the quality of the loan portfolio, in contrast to the above variables, have significant effects. The 100 basis points increase in the market share of the bank regarding commercial loans in the $t$ period leads to an increase of approximately 2.3 basis points in the commercial loan interest rate in the $t+1$ period. This situation can be seen as the proof of an oligopolistic structure. Considering that the difference between the highest and lowest interest rates in commercial loan interest rates during the period under investigation is 9.8 points on average, it is understood that $1 / 4$ of this difference stems from the market share. This situation strengthens our prediction of an oligopolistic structure. It becomes clearer when evaluated together with the weight of state-owned banks in the Turkish banking system. It is observed that the deterioration in the commercial credit quality of the banks has a positive impact on the interest rate in total. Since credit quality is defined as the ratio of non-performing loans to total loans, the increase in this rate indicates the deterioration in loan quality. The 100 basis points increase in the ratio in period $t$ results in an increase of 4.4 basis points in the loan interest rate in $t$ and $t+1$ periods. Considering that the coefficient obtained for the leverage value is quite small, it shows that the banking system is more agile in transmitting the credit risk to the customers using credit. However, we should immediately point out that since various types of loans are combined under the heading of commercial loans, the interest rates applied to these loan types are spread over a wide range. This differentiation is due to the fact that the interest rate changes according to the characteristics of the borrowers and the term of the loan. For example, while large-scale companies are in preferred customer status, borrowing costs may be higher for small-scale businesses.

According to the "omitted variables test" for the commercial loan interest rate summarized in Table 5, it is understood that the variables not included in the estimated model are not statistically significant as a whole. The results of the "cross-section dependency tests" regarding the independence of the residual terms (Table 6) indicate that the weighted residual terms obtained from the model estimated for the commercial loan interest rate are not correlated. According to the results obtained so far, the transmission in consumer loans is larger than commercial loans during the analyzing period. This is because the elasticity of demand in consumer loans is more rigid, rather than the intensity of competition or risk 
assessment.

Table 5: Omitted Variables Tests

\begin{tabular}{|l|l|l|l|l|l|l|}
\hline Equation for & $\mathrm{F}$ & $\begin{array}{l}\text { Degrees of } \\
\text { freedom }\end{array}$ & Probability & $\begin{array}{l}\text { Likelihood } \\
\text { Ratio }\end{array}$ & $\begin{array}{l}\text { Degrees } \\
\text { of freedom }\end{array}$ & Probability \\
\hline$R C O M$ & 1.1655 & $12 ; 709$ & 0.3041 & 14.2790 & 12 & 0.2833 \\
\hline$R C O N$ & 1.2886 & $12 ; 708$ & 0.2759 & 12.4421 & 12 & 0.3212 \\
\hline
\end{tabular}

Table 6. Cross Section Dependency Tests

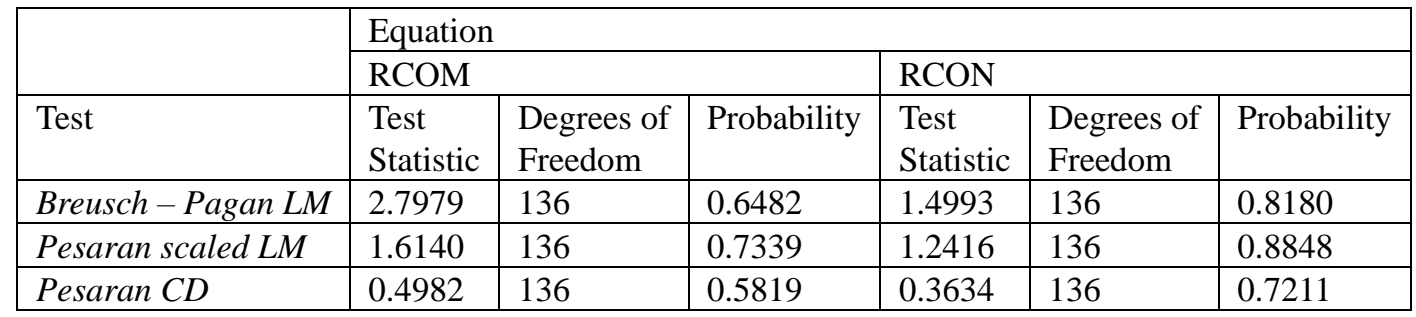

When the estimation results of consumer loan interest rates are analyzed, the determining factors are policy interest rate (current and lagged), bank size (lagged), leverage (lagged), market power (lagged), market share (lagged), credit quality (current and lagged) and return on assets. First of all, it is seen that bank-specific characteristics which determine consumer loan interest rates entered into the model with a lag. While banks react mostly in the current period in commercial loans to policy interest rate changes, they generally give a one-period lagged response in consumer loans. On the other hand, the average real interest rate on consumer loans over the period is 6.2 percent, about 600 basis points higher than the average policy rate. Considering that the commercial loan average interest rate and the average policy interest rate spread were approximately 800 basis points during the review period, it is understood that the default risk in consumer loans is perceived to be lower. This finding is the main factor behind the inclusion of explanatory variables in consumer loans, usually with a one-quarter lag.

As with commercial loan interest rates, there is high inertia in consumer loan interest rates. An increase of 100 basis points in the cost of borrowing in the previous period results in an increase of approximately 88 basis points in the consumer loan interest rate for the current period. Considering the monetary policy decisions, results demonstrate that the 100 basis point increase in the policy interest rate was reflected in the consumer loan interest rate as an increase of approximately 15 basis points in a two-quarter period.

The coefficients of the variables related to bank characteristics in the estimated consumer loan interest rate model overlap with the commercial loan interest rate model, except for a few variables. Primarily, although they are statistically significant at traditional significance levels, the effects of lagged bank size, lagged leverage, and market power on consumer loan interest rates are quite small. A one-point increase in these variables will cause a -0.0022 , -0.0008 , and 0.0001-point change in the consumer loan interest rate, respectively. While the 
coefficient of the leverage has the opposite sign of the expected, other coefficients have the expected sign. In terms of consumer loan interest rates, the market share of the bank, the quality of the loan portfolio, and the return on assets ratio create significant effects when compared with the variables listed above. A 100 basis points increase in the market share of the bank in consumer loans in period $t$ is reflected as an increase of approximately 4.4 basis points in the consumer loan interest rate in the $t+1$ period. This is the result of the rigidity of demand elasticity in consumer loans, which we mentioned earlier. It is understood that the deterioration in the quality of consumer loans given by the bank (the increase in the ratio of non-performing loans to total loans) is positively transferred to the interest rate of such loans. In this ratio, which we call the quality indicator, the deterioration (increase) of 100 basis points in the $t$ period is reflected as a 3.2 basis point increase in the consumer loan interest rate in the $t$ and $t+1$ period. The 100 basis points increase observed in the bank's return on assets in the $t$ period results in a decrease of approximately 11 basis points in the $t+1$ period's consumer loan interest rate. This situation can be evaluated as a result of the inverse relationship between the policy rate and the intermediation margin. For example, when the Monetary Policy Committee decides to increase the policy rate, the intermediation margin of financial institutions tends to decrease in the first months. The reason for this is that while the deposit interest rate increases close to the policy rate in the short term, the loan interest rates gradually adjust to this increase. Thus, an inverse relationship emerges between the policy rate (and, therefore, the loan interest rate) and the return on assets in the short run. However, the obtained coefficient is significant only at the $10 \%$ significance level, even though it has a sign in line with our theoretical expectations.

The tests for the variables omitted from the estimated consumer loan interest rate model (Table 5) and the tests for the independence of the residuals (Table 6) indicate the consistency of the estimation results.

\section{Conclusions and Policy Recommendations}

This study aims to examine the monetary policy transmission through the credit channel from a microeconomic perspective. In the study, it is estimated to what extent policy interest rate changes are transferred to the short-term interest rate depending on the type of loan. The preferred econometric specification is the fixed effect dynamic panel model, which solves the autocorrelation in error terms and heteroscedasticity. By capturing the observable and unobservable differences between banks and their effect on the loan interest rate, this model provides the opportunity to determine the transmission to the market interest rate.

Considering that the loan demand reacts to the supports provided in the long term, it should be noted that short-term analysis is essential in interest rate transmission. In principle, the effect to be observed in the long run should be greater than that in the short run. However, this situation emerges as an accumulation of gradual changes that are of greater importance in the short term.

According to the results obtained, there is a high degree of inertia in both the commercial and consumer loan interest rates. In terms of the transmission of monetary policy, changes in policy interest rates in the short term are transferred to commercial loan interest rates by $11 \%$ 
and consumer loan interest rates by $15 \%$. These values reveal that policy interest rate changes are gradually transmitted to market interest rates. The resistance of loan interest rates to adapt to policy rate changes is a natural consequence of the fact that a small portion of total loans has a variable rate.

Variables representing bank size, leverage, and market power in terms of distinctive characteristics have a limited impact on both commercial and consumer loan interest rates in the analyzing period. In the context of commercial loans, the increase in the market share of the bank and the deterioration in the quality of the loan portfolio put upward pressure on the interest rate of such loans. The same effect exists in the context of consumer loans, and it is stronger than the transmission in commercial loan interest rates. The additional variable that exhibits a strong inverse transmission to the consumer loan interest rate is the return on assets. This situation can be evaluated as a result of the inverse relationship between the policy rate and the intermediation margin.

In terms of policy recommendations, it is appropriate to encourage a structure that is more adaptable to policy interest rate changes in normal periods (i.e., moderate demand shocks) with applications such as variable rate loan interest rates. In addition, considering the "positive relationship between interest rate and market share", which is true for both types of loans, it would be a rational policy choice for regulatory agencies to make regulations encouraging competition in the financial sector. Increasing competition will reduce the interest rate differences among institutions and the loan interest rate - policy interest rate spread.

Contrary to normal periods, in case of significant demand shocks (such as the deterioration in economic activities due to the coronavirus), it would be appropriate to support policy rate changes with other tools that will accelerate the transmission of monetary policy. While reserve changes in the banking system can fulfill this task in the short term, forward guidance will gain importance in the long term. The last point mentioned is beyond the scope of this study.

\section{References}

Altinoz, C., \& Ozdemir, N. (2012). Determinants of interest rate pass-through for emerging market economies: The role of financial market structure. International Advances in Economic Research, 18(4), 397-407. https://doi.org/10.1007/s11294-012-9377-9

Aydemir, R., \& Ovenc, G. (2016). Interest rates, the yield curve and bank profitability in an emerging market economy. Economic Systems, 40(4), 670-682.

https://doi.org/10.1016/j.ecosys.2016.04.003

Aydın, B., \& Igan, D. (2012). Bank lending in Turkey: Effects of monetary and fiscal policies. Emerging Markets Finance and Trade, 48(5), 78-104.

https://doi.org/10.2753/REE1540-496X480505

Bernanke, B. S., \& Gertler, M. (1995). Inside the black box: The credit channel of monetary policy transmission. Journal of Economic Perspectives, 9(4), 27-48. 
https://doi.org/10.1257/jep.9.4.27

Binici, M., Kara, H., \& Ozlu, P. (2019). Monetary transmission with multiple rates: Evidence from Turkey. Applied Economics, 51(17), 1869-1893.

https://doi.org/10.1080/00036846.2018.1529400

Byrne, D., \& Kelly, R. (2019). Bank assets quality and monetary policy pass-through. Applied Economics, 51(23), 2501-2521. https://doi.org/10.1080/00036846.2018.1546953

Catik, A. N., \& Karacuka, M. (2012). The bank lending channel in Turkey: Has it changed after the low-inflation regime. Applied Economics Letters, 19(13), 1237-1242.

https://doi.org/10.1080/13504851.2011.619479

Cruz-Garcia, P., Fernandez de Guevara, J., \& Maudos, J. (2019). Determinants of bank's interest margin in the aftermath of the crisis: The effect of interest rates and the yield curve slope. Empirical Economics, 56(1), https://doi.org/10.1007/s00181-017-1360-0

De Fiore, F., \& Tristani, O. (2013). Optimal monetary policy in a model of the credit channel. The Economic Journal, 123(571), 906-931. https://doi.org/10.1111/j.1468-0297.2012.02558.x

Endut, N., Morley, J., \& Tien, P. (2018). The changing transmission mechanism of US monetary policy. Empirical Economics, 54(1), 959-987.

https://doi.org/10.1007/s00181-017-1240-7

Fuertes, A. M., Heffernan, S., \& Kalotychou, E. (2010). How the UK banks react to changing central bank rates? Journal of Financial Services Research, 37(2), 99-130.

https://doi.org/10.1007/s10693-009-0056-9

Gambacorta, L., \& Shin, H. S. (2018). Why bank capital matters for monetary policy? Journal of Financial Intermediation, 35, 17-29. https://doi.org/10.1016/j.jfi.2016.09.005

Gregor, J., \& Melecky, M. (2018). The pass-through of monetary policy rate to lending rates: The role of macro-financial factors. Economic Modelling, 73, 71-88.

https://doi.org/10.1016/j.econmod.2018.03.003

Holton, S., \& Rodriguez, A. C. (2018). Interest rate pass-through since the Euro area crisis. Journal of Banking and Finance, 96, 277-291. https://doi.org/10.1016/j.jbankfin.2018.08.012

Karagiannis, S., Panagopoulos, Y., \& Vlamis, P. (2014). The response of bank retail rates to money market rates in the BRIC economies: An application of the disaggregated GETS model. Emerging Markets Finance and Trade, 50(2), 153-168.

https://doi.org/10.2753/REE1540-496X500209

Kashyap, A. K., \& Stein, J. C. (2000). What do a million observations on banks say about the transmission of monetary policy? American Economic Review, 90(3), 407-428.

https://doi.org/10.1257/aer.90.3.407

Khan, M. H., \& Khan, B. (2010). What drives interest rate spreads of commercial banks in Pakistan? Empirical evidence based on panel data. State Bank of Pakistan Research Bulletin, 6(2), 15-36. [Online] Available: 
https://www.sbp.org.pk/research/bulletin/2010/Vol6No.2/MahmoodBilal.pdf

Liu, B., Liu, C., \& Peng, J. (2018). Interest rate pass-through in China: An analysis of Chinese commercial banks. Emerging Markets Finance and Trade, 54(13), 3051-3063.

https://doi.org/10.1080/1540496X.2018.1438258

Sahin, A. (2019). Does trade credit channel operate in Turkey? An analysis with CBRT sector statistics. Ege Academic Review, 19(4), 437-455. https://doi.org/0.21121/eab.486249

Sengonul, A., \& Thorbecke, W. (2005). The effect of monetary policy on bank lending in Turkey. Applied Financial Economics, 15(13), 931-934.

https://doi.org/10.1080/0960310050010225

Stanislawska, E. (2015). Interest rate pass-through in Poland: Evidence from individual bank data. Eastern European Economics, 53(1), 3-24.

https://doi.org/10.1080/00128775.2015.1033362

Turguttopbas, N. (2019). The bank lending channel of monetary transmission in Turkey. Business and Economics Research Journal, 10(2), 313-326.

https://doi.org/10.20409/berj.2019.170

van Leuvensteijn, M., Sorensen, C. K., Bikker, J. A., \& Rixtel, A. (2013). Impact of bank competition on the interest rate pass-through in the Euro area. Applied Economics, 45(11), 1359-1380. https://doi.org/10.1080/00036846.2011.617697

\section{Appendix}

List of the Banks Included in the Panel Data

\begin{tabular}{|l|l|l|l|l|}
\hline CODE & Name & Capital Ownership & Data (Quarterly) & Data Source \\
\hline 1 & Akbank & Private & $2010-2020$ & BAT $^{*}$ \\
\hline 2 & Alternatifbank & Private & $2010-2020$ & BAT \\
\hline 3 & Anadolubank & Private & $2010-2020$ & BAT \\
\hline 4 & Denizbank & Private & $2010-2020$ & BAT \\
\hline 5 & GarantiBBVA & Private & $2010-2020$ & BAT \\
\hline 6 & Halkbank & Public & $2010-2020$ & BAT \\
\hline 7 & HSBC & Private & $2010-2020$ & BAT \\
\hline 8 & ING & Private & $2010-2020$ & BAT \\
\hline 9 & Isbank & Private & $2010-2020$ & BAT \\
\hline 10 & QNB & Private & $2010-2020$ & BAT \\
\hline 11 & Sekerbank & Private & $2010-2020$ & BAT \\
\hline 12 & TEB & Private & $2010-2020$ & BAT \\
\hline 13 & Turkishbank & Private & $2010-2020$ & BAT \\
\hline 14 & Turklandbank & Private & $2010-2020$ & BAT \\
\hline 15 & Vakifbank & Public & $2010-2020$ & BAT \\
\hline 16 & YapiKredi & Private & $2010-2020$ & BAT \\
\hline 17 & Ziraatbank & Public & $2010-2020$ & BAT \\
\hline
\end{tabular}

(*) BAT refers to the Banks Association of Turkey. 


\section{Copyright Disclaimer}

Copyright for this article is retained by the author(s), with first publication rights granted to the journal.

This is an open-access article distributed under the terms and conditions of the Creative Commons Attribution license (http://creativecommons.org/licenses/by/4.0/). 